\title{
An Accounting Program Merit Pay Survey
}

David H. Lindsay, California State University, Stanislaus, USA

Annhenrie Campbell, California State University, Stanislaus, USA

Kim B. Tan, California State University, Stanislaus, USA

Andrew Wagner, California State University, Stanislaus, USA

\begin{abstract}
Basing the compensation of accounting professors on merit pay in order to encourage better teaching, research and service is controversial. Before the effectiveness of merit-based salary plans can be examined empirically, it must be determined which accounting programs use such a system. In this study, the 852 accounting programs in the United States were surveyed to identify the methods in use to adjust the salaries of individual professors. Initial findings indicate that schools using a merit system usually do not also offer time in grade increases and that doctoral granting schools and AACSB accredited schools are more likely to use a merit system.
\end{abstract}

Keywords: merit pay, salary adjustment techniques, accounting programs

\section{INTRODUCTION}

\section{Motivation for this Study}

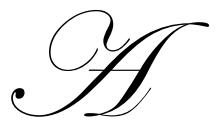

$\mathrm{n}$ article in the Philadelphia Inquirer, dated September 27, 2008, read:

A dispute is brewing within Temple University's faculty as its union pushes for largely across-theboard raises while nonunion members advocate merit pay. . . The union, however, says the university is pushing for all merit-pay increases. The contract expires Oct. 15.

A later article dated September 15, 2009, reads:

Temple University faculty members have approved a tentative four-year contract reached with the university last month. About 95 percent of those voting Monday approved the pact, union officials said. .. The employees would get no base increase or bonus in the first year, which is retroactive to October 2008, but would be eligible for a 1 percent merit pool.

Anecdotal evidence such as this suggests that merit pay for professors is becoming more common at the university level, but can this be shown empirically?

\section{The Need for a Survey of Accounting Programs}

Colleges and universities use widely varying compensation structures. Periodically, the College and University Personnel Association (CUPA) surveys over 3,000 higher education institutions regarding the policies and methods in place to adjust individual faculty salaries. Their survey considers a number of methods including: annual general wage adjustment, automatic length of service adjustment, use of a merit pay plan, lump sum incentive payments, bonus, gainsharing, and skill-and competency-based pay and team incentives. The CUPA (1999) data indicates that merit pay systems were in use at that time by 23.7 percent of responding institutions and compensation plans combining across-the-board pay raises with merit pay were used by another 26.4 percent of institutions. Since the data was aggregated, there is no way of knowing which individual schools, or individual disciplines within schools, use a merit-based pay system.

The rationale behind merit pay systems is to reward and thus encourage better performance in the key areas of faculty responsibility: teaching, research and service. Some kind of performance measure is required in order to operationalize such a pay plan. A professor's teaching performance may be measured with student evaluations or 
outcomes assessment tests, such as the ETS (once called the Educational Testing Service) Major Field tests (ETS, 2006). Usually some count of a professor's publications is used as the measure of research performance. It has proven most problematic to find an acceptable objective measure of service that is reasonably consistent across campuses.

The usefulness of merit pay is usually controversial at each institution where it is proposed including the University of Oxford in the United Kingdom which conducted a five-year study on the issue (THE, 2010). Given the ongoing controversy, we want to determine whether the existence of a merit pay system might be an institutional determinant of good teaching outcomes for accounting programs. The teaching outcomes can be measured using CPA exam pass rates. We further want to determine whether the existence of a merit system might also be an institutional determinant influencing faculty research output. However, before these issues can be examined we need to determine which schools in the U.S. with accounting programs use merit pay systems and which do not. Hence, a survey needs to be conducted.

\section{LITERATURE REVIEW}

Increasing restrictions on public funding and a desire on the part of university administrators for greater discretion to set faculty salaries have encouraged a move away from more traditional seniority-based compensation systems to the use of some form of merit pay (Grant, 1998). For merit pay to be feasible, however, there must be a clear link between individual effort and performance, and that performance must be accurately measured (Heneman \& Young, 1991). It has been vociferously argued that merit pay schemes are just not practical in a university setting, because the performance of individual faculty members is too difficult or specialized to measure objectively and measurement is likely to be too subjective (Johnston, 1978).

In general, the purpose of merit pay is to provide an incentive or motivating force to push a worker, whether a laborer, a government employee, or a college professor, to greater productivity (Miller, 1979). Merit pay for teachers is hardly a new idea; it was first used in England in the 19th Century (Holmes, 1920).

A field study of public school deans' perspectives showed that deans do believe merit pay promotes better teachers and higher quality research output, (Taylor, Lesher, Hunnicutt, Garland \& Keefe, 1991). However, this study is evidence only of opinions. We believe that, in the context of an accounting program, the question of the value or effectiveness of merit pay can be addressed as an empirical issue. But first, we must determine which schools use merit pay systems.

This study is an update of our previous examination of merit pay for accounting professors (Campbell, et al, 2010). Since the date of the initial study, deteriorating economic conditions have seriously impacted compensation levels and practices in all economic sectors including higher education. The current study accesses a larger sample of respondents, uses a different survey technique and applies a different statistical methodology to the resulting data set.

\section{METHODOLOGY}

The e-mail addresses of department chairs of the 852 accounting programs in the United States were identified using Hasselback's Accounting Faculty Directory 2008-2009. Using the Survey Monkey service, each of the chairs was e-mailed a survey structured along the lines of the CUPA taxonomy of methods currently used to adjust individual salary rates. The chairs were asked to respond with respect to the methods used during 2007, 2008 and 2009. In addition to the CUPA taxonomy, there were questions concerning furloughs and permanent across the board pay reductions -- issues not pertinent at the time of the previous study. A copy of the cover letter is presented in Exhibit 1 and a copy of the survey is presented in Exhibit 2.

Use of the various methods of salary adjustment need not be mutually exclusive. Since we are examining the relationship among indicator, yes/no, variables rather than continuous variables, it might not be appropriate to calculate Pearson correlation coefficients. Consequently, the relationship between use of the methods was analyzed using SPSS crosstabs tables. 
Crosstabs tables were also used to examine two other questions: 1) are doctoral institutions more or less likely to adopt merit programs than non-doctoral institutions, and 2) are AACSB-accredited institutions more or less likely to adopt merit programs than non AACSB-accredited institutions?

\section{RESULTS}

A survey was prepared using the free, online tool, Survey Monkey (www.surveymonkey.com). Survey Monkey maintains a database of respondent email addresses that have chosen not to participate in any Survey Monkey mediated questionnaires. Of the 852 schools sent the survey, 55 addressees had previously opted out. The total number of surveys actually received by recipients was 797 . Of these, 180 responded, yielding a response rate of 22.58 percent.

As seen in table 1, only 3 types of faculty salary adjustments were widely used:

COLA was used by $121(67.2 \%)$ schools in 2007, STEPS was used by $15(8.3 \%)$ schools in 2007 and merit was used by $101(56.1 \%)$ schools in 2007. The frequency of use of the COLA and merit methods decreased over the three year period.

Table 2 shows that the use of the three primary methods of salary adjustment was not mutually exclusive. Crosstabs analysis was performed to determine what percent of schools that use merit methods also use COLA or STEPS. From the table, It is clear that merit schools are far less likely to award time in grade pay raises than nonmerit schools. In 2007, a much higher percent of non-merit schools used COLA than did merit schools. This relationship vanished by 2009 , possibly as a result of the recession.

Table 3 addresses two additional questions: are doctoral institutions more or less likely to adopt merit programs than non-doctoral institutions, and are AACSB-accredited institutions more or less likely to adopt merit than non AACSB-accredited institutions? Over the three year period, doctoral institutions are more likely to use a merit program than non-doctoral institutions. Also, over the three year period, AACSB-accredited institutions are more likely to use a merit program than non AACSB-accredited institutions.

Lastly, table 4 shows the results of the crosstabs analysis that examined the relationship between furloughs and the use of COLA, steps and merit pay in the year 2009. Schools on furlough tend not to offer salary increases of any sort.

\section{FUTURE RESEARCH}

The results from this survey will be used in future work to understand whether the presence of a merit pay system is an institutional determinant of teaching outcomes and research output.

Table 1

Number and Percent of Schools Using a Specific Salary Adjustment Method

\begin{tabular}{|c|c|c|c|c|c|c|}
\hline \multirow[b]{3}{*}{ COLA } & \multicolumn{5}{|c|}{$\mathrm{n}=180$} & \multirow[b]{2}{*}{$\underline{\%}$} \\
\hline & 2007 & $\underline{\%}$ & 2008 & $\underline{\%}$ & 2009 & \\
\hline & $\overline{121}$ & $6 \overline{7.22}$ & $\overline{108}$ & $\overline{60}$ & $\overline{79}$ & $4 \overline{3.9}$ \\
\hline Steps & 15 & 8.333 & 16 & 8.89 & 14 & 7.78 \\
\hline Merit & 101 & 56.11 & 89 & 49.4 & 65 & 36.1 \\
\hline Lump Sum & 2 & 1.111 & 4 & 2.22 & 2 & 1.11 \\
\hline Bonus & 5 & 2.778 & 5 & 2.78 & 5 & 2.78 \\
\hline Gainsharing & 1 & 0.556 & 0 & 0 & 1 & 0.56 \\
\hline Skill-Based & 9 & 5 & 10 & 5.56 & 4 & 2.22 \\
\hline Team Based & 1 & 0.556 & 1 & 0.56 & 1 & 0.56 \\
\hline Furlough & 0 & 0 & 2 & 1.11 & 22 & 12.2 \\
\hline Pay Cut & 0 & 0 & 1 & 0.56 & 4 & 2.22 \\
\hline
\end{tabular}


Table 2

Crosstabs Analysis of Merit Schools Also Using Other Salary Adjustment Methods

Panel A: Percent of Merit Schools Using Steps

$\begin{array}{lll}\text { Year } & \text { Merit Schools } & \text { Non-Merit Schools } \\ 2007 & 2 & 19.1 \\ 2008 & 2.2 & 17.5 \\ 2009 & 1.5 & 13.5\end{array}$

Panel B: Percent of Merit Schools Using COLA

$\begin{array}{lll} & \text { Merit Schools } & \text { Non-Merit Schools } \\ \text { Year } & & \\ 2007 & 60.4 & 88.6 \\ 2008 & 61.8 & 66.3 \\ 2009 & 50.8 & 44.2\end{array}$

Table 3

Crosstabs Analysis of Doctoral Schools and AACSB Accredited Schools Use of Merit

Panel A: Percent of Doctoral Schools Using Merit

$\begin{array}{lll}\text { Year } & & \\ 2007 & 75 & 59.5 \\ 2008 & 75 & 51.4 \\ 2009 & 50 & 37.8\end{array}$

Panel B: Percent of AACSB Accredited Schools Using Merit

$\begin{array}{lll}\text { Year } & \text { Accredited } & \text { Non-Accredited } \\ 2007 & 70 & 30 \\ 2008 & 59 & 45.3 \\ 2009 & 43 & 32.8\end{array}$

Table 4

Percent of 2009 Furlough Schools Using COLA, Steps or Merit

Method

COLA

Steps

Furlough

Non-Furlough

Merit

$\begin{array}{ll}9.1 & 52.4 \\ 0 & 10.2 \\ 18.2 & 41.5\end{array}$

\section{AUTHOR INFORMATION}

Annhenrie Campbell, Ph.D., CPA, CMA, CGFM is a Professor of Accounting at California State University, Stanislaus. She holds a Ph.D. from the University of Colorado in Boulder. Her research interests include the impact of faculty research on students' professional preparation and academic success. She teaches advanced financial accounting and governmental accounting courses.

David H. Lindsay, Ph.D., CPA (inactive), CISA, CFE is a Professor of Accounting and the Chair of the Department of Accounting and Finance at California State University, Stanislaus. His Ph.D. is from the Graduate School of Management at Kent State University. His research interests include determinants of CPA Exam pass rates, the impact of merit programs on research and teaching outcomes, fraud detection, and various AACSB related issues. He teaches Intermediate Accounting I and II. 
Kim Tan, Ph.D., CA is a Professor at California State University Stanislaus. Her Ph.D. in Business Administration is from Temple University in Philadelphia. She's a Chartered Accountant with the New Zealand Society of Accountants and a member of the Australian Computer Society. She is interested in pedagogical and behavioral research using experimental, archival and survey data. She mainly teaches Cost and Managerial Accounting.

Andrew J. Wagner is professor of finance and program director of the Master of Science in Business Administration (MSBA) program at California State University, Stanislaus. He specializes in the areas of international finance and derivative securities. Originally from Philadelphia, Pennsylvania, Andrew received his Ph.D. from Texas A\&M University. Andrew is married and has three beautiful daughters.

\section{REFERENCES}

1. Bragg, T.A. (1994, May). "The Use of Occupational Licensure Examination Results in Outcomes Assessment." Paper presented at the meeting of the Association for Institutional Research, New Orleans, LA.

2. Campbell, Annhenrie, D.H. Lindsay, D.E. Garner \& K.B. Tan. (2010, April”. “The Impact of Merit Pay on Research Outcomes for Accounting Professors." Contemporary Issues in Education Research, 3,(4), 55-62.

3. College and University Personnel Association (1999). Survey of Compensation Practices in Higher Education. Washington, D.C., 17.

4. College Board, (2006). History. Retrieved May 25,2006, from the College Board website: http://www.collegeboard.com/about/association/history.html

5. DeBerg, C.L. \& Wilson J.R. (1990). An Empirical Investigation of the Potential Confounding Variables in Student Evaluation of Teaching. Journal of Accounting Education. 8, 37-62.

6. Dunn, W. M. \& Hall T.W. (1984). CPA Exam Performance-Can It Be Explained. The Woman CPA. 46,(2), 10-14.

7. ETS (2006). Our Heritage. Retrieved May 25, 2006 from ETS website: www.ets.org.

8. Feldman, K.A. (1987). "Research Productivity and Scholarly Accomplishment of College Teachers as Related to Their Instructional Effectiveness: A Review and Exploration." Research in Higher Education, 26,(3), 227-298.

9. Johnston, J.J. (1978). “Merit Pay for College Faculty?” Advanced Management Journal, 43,(2), 44.

10. Grant, H.(1998). "Academic contests? Merit Pay in Canadian Universities." Relations Industrielles, (Quebec), 53,(4), 647-667.

11. Hasselback, J.R. (2008). Accounting Faculty Directory 2008-2009. Upper Saddle River, NJ.: Prentice Hall.

12. Heneman, H.G. \& Young I.P. (1991). "Assessment of a Merit Pay Program for School District Administrators." Public Personnel Management, 20(1), 35-48.

13. Holmes, E. G. A. (1920). In Quest of an Ideal. London: Cobden-Sanderson, 62.

14. Jamiesen, S. \& Curtis, F. (2000). "Some Thoughts on our Merit Pay Discussions." Retrieved October 15, 2005 from the Drew University AAUP (American Association of University Professors) website: http://www.depts.drew.edu/aaup/merit.htm

15. Miller, Ernest C. "Pay for Performance." Personnel, 56, (4), 1979, 4.

16. Schick, A. G. (1998). Should Undergraduate Education in Accounting be Evaluated, in Part, Based on Graduates' Performance on the CPA Examination. Issues in Accounting Education. 13,(2). 417-421.

17. Taylor, R.L., Garland,G.H., Hunnicutt, G. \& Keefe.J. M. (1991). "Merit Pay in Academia: Historical Perspectives and Contemporary Perceptions." Review of Public Personnel Administration, 11(3), 51-65.

18. THE (2010). Oxford Report - Goodbye readers, hello merit pay. Retrieved May 15, 2010 from the THE website: www.timeshighereducation.co.uk. 


\section{Exhibit 1 \\ Survey Cover Letter}

To: [Email]

From: dlindsay@csustan.edu

Subject: Accounting Department Merit Survey

Body: Dear Department Chair [LastName]:

My colleagues, Dr. Annhenrie Campbell and Dr. Kim B. Tan, and I are asking you to take a few minutes to complete a survey for our research study on methods used to adjust individual faculty salaries.

The survey will take you just a few minutes to complete. The survey is being administered via Survey Monkey utilizing the following link.

[Insert Link Here]

This link is uniquely tied to this survey and your email address. Please do not forward this message.

Your responses will be pooled with others for statistical analysis. No specific individual response will be discussed or disclosed.

Your participation is completely voluntary. While you may choose to disregard this request, we hope you decide to participate in our study.

Please contact me with any questions or concerns you may have regarding this project.

Best regards,

David H. Lindsay, Ph.D.

Professor of Accounting

California State University, Stanislaus

Phone: (209) 667-3296

Please note: If you do not wish to receive further emails from us, please click the link below, and you will be automatically removed from our mailing list.

[Insert Link Here] 


\section{Exhibit 2}

\section{Accounting Program Merit Pay Survey}

This is a survey of the methods used to arrive at individual faculty salary amounts in accounting programs. Please check all items applicable to your department's procedures in the years 2007, 2008, and 2009.

Annual General Wage Adjustment

Automatic Length of Service Adjustment

Merit Pay Plan

Lump Sum Incentive Payment

Bonus

Gainsharing

Skill- and Competency Based Pay

Team Incentives

Furlough

Across the Board Pay Reduction

\begin{tabular}{|c|c|c|}
\hline 2007 & 2008 & 2009 \\
\hline [] & [] & [] \\
\hline [ ] & [ ] & [ ] \\
\hline [ ] & [ ] & [ ] \\
\hline [ ] & [ ] & [ ] \\
\hline [ ] & [ ] & [] \\
\hline [ ] & [ ] & [ ] \\
\hline [ ] & [ ] & [ ] \\
\hline [ ] & [ ] & [ ] \\
\hline [ ] & [ ] & [ ] \\
\hline [ ] & [ ] & [ ] \\
\hline
\end{tabular}

THANK YOU FOR YOUR PARTICIPATION 
NOTES 